\title{
HURRICANE MATHEW VS. HILTON HEAD ISLAND, SOUTH CAROLINA
}

\author{
Adrián Kráner, Lucia Šolcová
}

\begin{abstract}
The Atlantic tropical-cyclone basin is one of six in the world and includes much of the North Atlantic Ocean, the Caribbean Sea, and the Gulf of Mexico. Hurricanes are products of the interaction between tropical oceans and the atmosphere. Powered by heat from the sea, they are steered by the easterly trade winds as well as by their own ferocious energy. Hurricanes and tropical storms are irregular visitors to coastal South Carolina. In the period, 1851-2016, only 38 tropical cyclones have made landfall on the South Carolina coast. Matthew formed from a tropical wave that pushed off the African coast in late September. African coast in late September. Despite the fact that hurricanes are the greatest threat to life and property, South Carolina communities are not required to develop disaster recovery plans by state law.
\end{abstract}

Keywords: tropical cyclone, Matthew, Hilton Head Island, South Carolina

\section{Introduction}

In the early 1950s, Hilton Head Island was used mainly for logging and its population was only 300 residents, it didn`t have electricity, phone service, gas stations or convenience stores. Only one paved road existed, and that was on the north end of the island. A state-operated car ferry began running from Buckingham Landing near Bluffton, on the mainland in 1953, a two lane swing bridge bridge connecting the island to the mainland was not constructed until 1956. At the time, the Lowcountry area of South Carolina was one of the poorest in the state. Charles Fraser, a graduate of Yale Law School, who`s family was in the timber business while surveying the land with his brother, saw potential in the dense forest leading to the Atlantic Ocean. According to Hefter (1998) The Fraser family, from Hinesville, Ga., along with the Hack Family, owned 20.000 acres on the south side of the island at that time. Charles Frazer, the Father of Modern Day Development of Hilton Head Island, purchased the land from his father, he had a vision to cut down only a few trees rather than completely level the area for the build out and created a master plan for a world class retirement resort called Sea Pines. To convert the swampy, mosquito infested area of the island required much forethought. His concept was a planned unit development with strict land-use and land-preservation covenants. Part of his research prior to development also involved a mosquito control program an innovation that radically improved year 
round living on the whole island (www.seapines50thanniversary.com).

Hilton Head Island is tied inexorably to golf and tennis. According to heritage classic foundation, it is a home to South Carolina's only PGA tour event, the Heritage PGA golf tournament played on Harbor Town Golf Links since 1969 that first introduced Sea Pines resort to the world at large. Thanks in part to the climate and its 300 tennis courts and 23 golf courses, golf and tennis on Hilton Head Island is a year round pursuit.

The Town of Hilton Head Island incorporated as a municipality in 1983 and is well known for its "ecofriendly" development based on Charles Frazer`s ideas, The Town`s Community Development Department enforces the Land Management Ordinance which minimizes the impact of development and governs the style of buildings and how they are situated amongst existing trees. As a result, Hilton Head Island enjoys an unusual amount of tree cover relative to the amount of development. A comprehensive tree ordinance in place since 1986 provides a robust urban forest that helps improve air quality by shading the built environment, cooling air temperature, and absorbing and breaking down air pollutants. Due to this ordinance, tree canopy on the island is greater than other communities in this area. Approximately $70 \%$ of the island, including most of the tourist areas, is located inside gated communities. However, the town maintains 7 beach Access points and parks. Residents have approved several multi-million dollar land acquisition bond referendums to control the amount or location of commercial growth; protect green blueprint, open space and the environment; and provide for active and passive public use such as 62 miles of pathways, 3 community parks and recreational facilities.

\section{Definition area}

Hilton Head Island is a resort town located on an island of the same name in Beaufort County, South Carolina, United States. It is 20 miles $(32 \mathrm{~km})$ north of Savannah, Georgia, and 95 miles $(153 \mathrm{~km})$ south of Charleston. The island gets its name from Captain William Hilton. In 1663, Captain Hilton identified a headland near the entrance to Port Royal Sound, which he named "Hilton's Head" after himself. The island features 12 miles $(19 \mathrm{~km})$ of beachfront on the Atlantic Ocean and is a popular vacation destination. In 2015 an estimated 2.65 million visitors pumped more than $\$ 1.1$ billion into the local economy. The year-round population was 40,039 (2014), although during the peak of summer vacation season, population can swell to 305,000 (2015) (Consolidated Municipal Budget Fiscal Year July 1, 2016 - June 30, 2017).

\section{The Atlantic tropical-cyclone basin}

The Beaufort County is vulnerable to a variety of hazards including tornadoes, flooding, earthquakes, wildfires, hazardous materials incidents, 
terrorism, power outages and resource shortages. All of these types of events could impact thousands of citizens across the county with significant financial impacts and possible tragic losses, however the most eminent threat to the people and property are hurricanes. Hurricane season begins on June 1 and continues through November 30 each year. To coincide with the start of the Atlantic Basin tropical season. Although this period is the predominant time of year for hurricanes to occur in the Atlantic Ocean, Gulf of Mexico and Caribbean Sea, tropical storms can and have formed in every month of the calendar year. The risk of an impact of tropical cyclones in South Carolina ranks near the top in a vulnerability assessment of natural hazards. Although only 6 of 46 counties including Beaufort county are along the immediate coastline of South Carolina, another 21 inland counties are at risk from the effects of tropical cyclones due to their low elevations and proximity to the Atlantic Ocean. The ever-growing coastal population and summer tourism industry on pristine beaches of Hilton Head Island create a great risk for the possibility of lost lives and property damage (Hurricane awareness in South Carolina).

The Atlantic tropical-cyclone basin is one of six in the world and includes much of the North Atlantic Ocean, the Caribbean Sea, and the Gulf of Mexico. A North Atlantic basin formed hurricane is a tropical cyclone with counter-clockwise rotation, heavy rain and winds that have reached a constant speed of 74 miles per hour or higher. The ingredients for a tropical cyclone include a pre-existing weather disturbance, warm tropical oceans, moisture, and relatively light winds aloft (Thermographic Documentation of Roof and Building Damage Incurred During the 2004 Florida Hurricane Season). When a hurricane forms, winds blow in a large spiral around a relative calm center known as the "eye." Early season tropical cyclones generally form in the western Caribbean Sea and the Gulf of Mexico. By the end of June or in early July, the area of formation shifts eastward.

As the summer progresses and the ocean waters warm, conditions become more favorable for tropical storm formation in late August, tropical cyclones form over a broad area of the eastern Atlantic, extending eastward to the area of the Cape Verde Islands off the coast of Africa. The period from about August 20 through about September 15 with a maximum frequency of storms in the second week of September encompasses the maximum of these Cape Verde storms. Most Cape Verde storms cross-vast areas of the Atlantic Ocean before dissipating over the North Atlantic. Those, which do make landfall in the United States can be especially powerful. The coastal sections of South Carolina and its barrier islands are particularly vulnerable to storms from the Atlantic Ocean (Hurricane preparedness in South Carolina).

By Mid-September, storm frequency begins to decline, the formative area retreats westward back to the Caribbean Sea and the Gulf of Mexico. Usually, by mid-November, tropical-cyclone occurrence in the North Atlantic has ceased (South Carolina State Climatology Office). 
As a hurricane nears land there are many hazards associated with hurricanes, including storm surge, heavy rainfall, inland flooding, high winds, tornadoes, and rip currents. Of these, storm surge has the most potential for loss of life on the coast. Storm surge is an abnormal rise in sea level accompanying a hurricane or other intense storm. This advancing surge combines with the normal tides and increases the water level to heights that will impact roads, homes and other critical infrastructure. This rise of water can cause severe flooding in coastal areas, particularly when the storm tide coincides with the normal high tide.

Storm surge is often 50 miles wide, which sweeps across the coastline near where the eye of the hurricane makes landfall. The surge, aided by the hammering effect of breaking waves, is like a giant bulldozer sweeping everything in its path. The stronger the hurricane, the higher the storm surge. This is unquestionably the most dangerous part of the hurricane. Nine out of ten hurricane fatalities are caused by the storm surge (figure 1,2) (www.hiltoheadislandsc.gov).

Figure 1: Cyclone storm surge

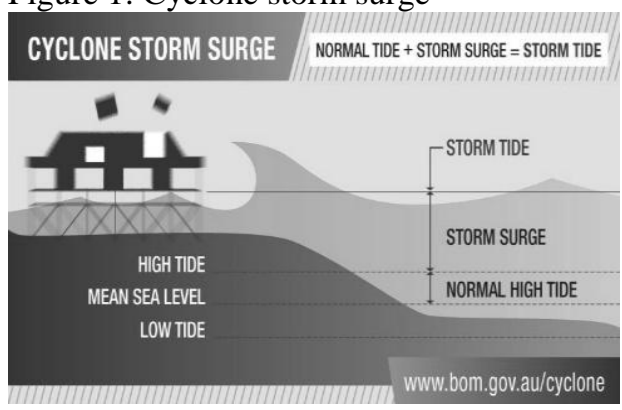

Source: http://www.abc.net.au/news/201701-9/what-is-storm-surge-and-how-canyou-prepare/8123274

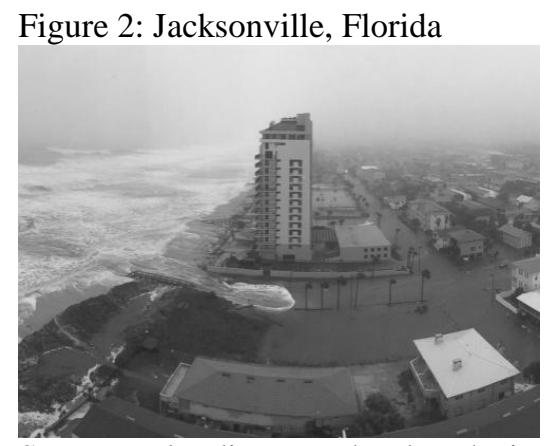

Source: Flooding at the beach in Jacksonville, Florida, Oct. 7, 2016. http://abcnews.go.com/US/hurricane -matthew-batters-florida-coast-deadmillion-lose/story?id=42608853

Tropical cyclones are classified as follows:

Tropical Depression: An organized system of clouds and thunderstorms with a defined circulation and maximum sustained winds of $38 \mathrm{mph}(61 \mathrm{kmh})$ or less.

Tropical Storm: An organized system of strong thunderstorms with a defined circulation and maximum sustained winds of 39 to $73 \mathrm{mph}(62-118 \mathrm{kmh})$.

Hurricane: An intense tropical weather system with a well-defined circulation and maximum sustained winds of $74 \mathrm{mph}(119 \mathrm{kmh})$ or higher. In the western Pacific, hurricanes are called "typhoons," and similar storms in the Indian Ocean are called "cyclones." Hurricanes are according to the Saffir-Simpson 
Hurricane Scale first used in 1975 (http://hurricane-facts.com) classified into 5 categories based on their wind speed, central pressure, and damage potential.

Hurricanes are products of the interaction between tropical oceans and the atmosphere. Powered by heat from the sea, they are steered by the easterly trade winds as well as by their own ferocious energy. Around their core, winds grow with great velocity, generating violent seas. Moving ashore, they sweep the ocean inward while spawning tornadoes and producing torrential rains and floods. Each year, on average, 10 tropical storms, of which six become hurricanes, develop over the Atlantic Ocean, Caribbean Sea, or Gulf of Mexico. Many of these remain over the ocean; however, about five hurricanes strike the United States coastline every three years. Of these five, two will be major hurricanes, category 3 or greater on the Saffir-Simpson Hurricane Scale (South Carolina hurricane guide, 2016).

Hurricanes and tropical storms are irregular visitors to coastal South Carolina. In the period, 1851-2016, only 38 tropical cyclones have made landfall on the South Carolina coast (24 hurricanes, 9 tropical/subtropical storms, 5 tropical depressions). Of these, ten were of Category 2 to Category 4 intensity. Since 1900, no Category 5 hurricanes have hit South Carolina. There have been three Category 4 hurricanes (Hazel, 1954, Gracie, 1959 and Hugo, 1989) (South Carolina State Climatology Office).

Looking at past hurricane events, they will show us that lack of hurricane awareness and preparation are common threads among all major hurricane disasters. Before hurricanes carried names and price tags, like New Orleans' Katrina (estimates start at about $\$ 100$ billion) and Florida's Andrew ( $\$ 44$ billion) and South Carolina's Hugo ( $\$ 12$ billion), a nameless storm slammed the islands clustered off Georgia and South Carolina. These islands were home to descendents from Africa, former slaves who were of the Gullah language and culture. Beaufort County, S.C., which includes many sea islands, got the worst of it. With little communication and no means of evacuation from the bridgeless islands, upward of 2,000 people (only two of them white) died in "The Sea Island Hurricane of 1893". The storm of 1893 was one of three big hurricanes to hit coastal South Carolina in one decade (The Sea Island Hurricane of 1893 by Betty Joyce Nash) It is possible that the "Great Storm of 1893" that struck the southern on coast on August 20 of that year was at least a Category 4 storm, but there was no way of accurately measuring tropical-cyclone intensity before 1900 .

Matthew formed from a tropical wave that pushed off the African coast in late September. That tropical wave was dubbed Invest 97L just southwest of the Cape Verde Islands on Sept. 25. It took a few days for that system to organize as it moved westward in the Atlantic. Hurricane Matthew started its destructive path in the Atlantic on Sept. 28, 2016 when it first became a Tropical Storm (figure 3,4). Once Matthew reached the eastern Caribbean, it became a hurricane and rapidly intensified. It was one of the strongest hurricanes to hit the East Coast in decades, with winds reaching $145 \mathrm{mph}$ with gusts up to $166 \mathrm{mph}$, according to the National 
Hurricane Center. Matthew oscillated between a category 3 and 4 hurricane when it caused the most damage, killing over 1000 people in Haiti and 44 in USA, causing major flooding, widespread evacuations and power outages and significant material damages (www.usa.today.gov).

The most powerful Atlantic storm since 2007 left flooding and wind damage in Florida, Georgia and the Carolinas. Wind speeds had dropped by nearly half from their peak to 75 miles per hour $(120 \mathrm{kph})$, reducing it to a Category 1 hurricane, when Matthew made one official U.S. landfall at 10.45am on Oct. 8 southeast of McClellanville, 95miles north from Hilton Head Island in South Carolina. However the southeastern United States were hit hard by Hurricane Matthew not due to the landfall it made in SC, but especially since it moved very close to the coasts of Florida, Georgia, South Carolina and North Carolina.

On October 5th, residents of Beaufort County received a mandatory evacuation notice from the Governor. An estimated 355,000 fled the coastal areas of South Carolina and more than 2.5 million people were forced to evacuate nationwide. On Saturday, October 8th around 2 a.m., Hilton Head Island faced Hurricane Matthew. Although downgraded to a category 1 hurricane, Matthew brought wind gusts up to $88 \mathrm{mph}(140 \mathrm{kph})$ with a storm surge of $121 / 2$ feet and 13.99 " inches of rain. (weather.com) Damages to roads, powerlines, water supply and structures were enough to keep Hilton Head Island closed to residents until October 11th. For those who attempted to return to the island before reentry was permitted, they were temporarily moved into Red Cross Shelters set up in surrounding towns. After the storm passed, the island was left without power and running water. Hilton Head's boil water advisory was lifted on Thursday October 13th; however, wastewater service remained an issue on parts of the island for several more days. By the weekend there were nearly 20,000 homes in Beaufort County still without power. The entire town of Hilton Head has come together to restore the island after the devastation left by Hurricane Matthew (http://www.spinnakerresorts.com).

There are no Federal requirements for developing disaster recovery and redevelopment plans but after decades of natural and manmade disasters and their impact on human lives and property, National Disaster Recovery Framework has established Federal requirements for developing disaster recovery and redevelopment plans. In addition, the Robert Stafford Act, as amended by the Disaster Mitigation Act of 2000, supports community-wide planning to reduce hazard vulnerabilities and recognizes the importance of relationships among mitigation, community-wide cooperation and community recovery (Beaufort county disaster recovery plan, 2011).

South Carolina communities are not required to develop disaster recovery plans by state law. Prior to drafting of the Recovery Plan, Beaufort County had developed disaster response policies and practices that had been in place for many years; however, Hurricane Katrina, which impacted the Louisiana, Mississippi and 
Alabama Gulf Coasts in August of 2005, exposed many disaster recovery issues and gaps in local, state and federal response and recovery efforts for many communities The 2005 hurricane season led many coastal communities to re-write their plans for recovery from Catastrophic disasters. Beaufort County, like many communities, is vulnerable to hurricanes. Despite long periods of calm, Beaufort County has experienced major disasters, including hurricanes, tornadoes and other natural disasters. Beaufort County has been proactive in increasing its ability and capacity to withstand and recover from a catastrophic disaster. Beaufort County Council created the Disaster Recovery Task Force and adopted a Disaster Recovery and Reconstruction Ordinance in 2008, which was amended in 2011 and 2016. The Recovery Ordinance established the operational basis for the Beaufort County Disaster Recovery Plan.

Figure 3: Matthew

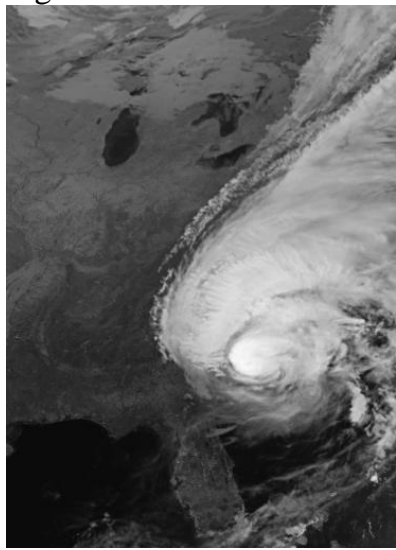

Source: Hurricane Matthew along the southeastern U.S. coast taken by NOAA's GOES-East satellite on Oct. 8, 2016, at 7:45 a.m. EDT
Figure 4: Mathew`s path

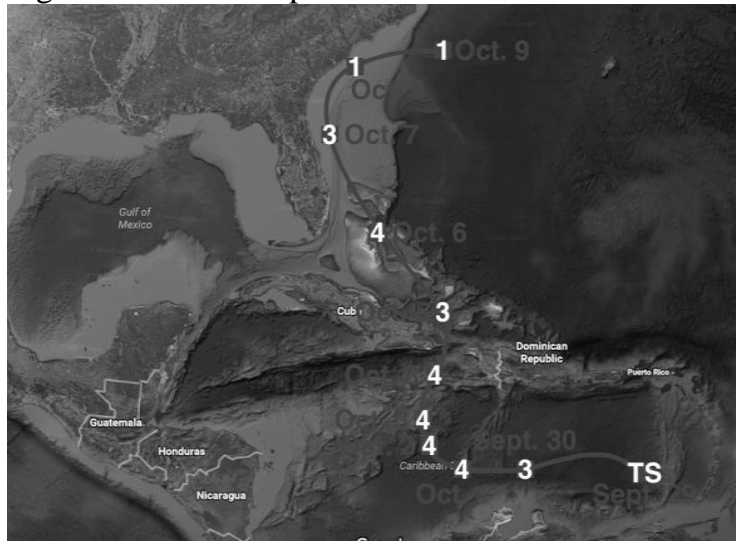

Source: Hurricane Mathew`s path, October 2016 http://www.cleveland.com/weather/blog/index.ssf/2 016/10/hurricane_matthew_recap_wind_s.html

The purpose of the Beaufort County Disaster Recovery Plan is to provide Beaufort County with a strategic plan to guide disaster recovery and redevelopment actions and decision-making. Additionally, the plan identifies Recovery Function actions that can be implemented prior to a disaster that will expedite recovery. The plan is built upon expanded recovery relationships among county departments, municipalities, businesses, non-governmental organizations, regional organizations and adjacent counties. The plan's strategic purposes are to position Beaufort County and municipalities to be in a better position to recover more effectively and 
expeditiously from a disaster, and to utilize redevelopment planning as an opportunity to build a more sustainable county and to enhance the quality of life of the county in general (Beaufort County Disaster recovery plan, 2016).

The Recovery Plan is designed to facilitate returning Beaufort County to pre-disaster conditions when feasible and to better position the County to maximize post-disaster opportunities to reduce hazard vulnerabilities.

Short- term Recovery efforts that greatly affect long term recovery and redevelopment success include:

1. Restoration of essential public services

2. Damage assessment

3. Emergency sheltering

4. Emergency and temporary housing

5. Business resumption

6. Debris management

The Recovery Plan provides an opportunity and framework for Beaufort County and municipalities within the county, to be in a better position to recover more rapidly. The Recovery Plan also addresses quality of life issues and pursuit of opportunities to reduce vulnerabilities. Municipalities within Beaufort County are engaged in disaster planning and preparation. Despite many shared issues and community characteristics, the Recovery Plan is based upon recognition that each jurisdiction has its own unique features and needs, and that municipal recovery strategies will vary to meet those needs. It is the County's objective to continue to include municipalities in recovery planning, recovery programs and recovery agreements.

The Town of Hilton Head Island has worked with county and state officials to develop comprehensive plans to respond effectively manage natural or human caused disasters. In addition, the town has also developed strategies to expedite and ease our recovery efforts by establishing an emergency reserve account to fund these activities and by amending the Land Management Ordinance to facilitate a rapid reestablishment of Hilton Head`s community following a hurricane or other disaster. (http://www.hiltonheadislandsc.gov/publicsafety/hurricane/)

The County's debris removal contractor is Ceres Environmental Services Inc debris monitoring contractor is R. W. Beck Disaster Recovery, Inc. They will be responsible for monitoring the debris removal contractor's work. However Hilton Head Island has developed a separate recovery plan for debris removal with Crowder Gulf Disaster Recovery and Tetra Tech as the debris removal monitor, due to the island's unique characteristics within the county. The other municipalities in the County have signed Memorandums of Agreements to have the county handle their debris operations. There are a large number of privatelyowned gated communities in Beaufort County especially on Hilton Head Island that will be looking to the County or the Town to remove their debris after a disaster. 
For the local people the reestablishment of the communities is the most important thing after a disaster but from the perspective of those responsible for reestablishing it, there is a very important question, "Who will pay for it?" When damages are so extensive that the combined local and state resources are not sufficient, the governor submits a request for an emergency or major disaster declaration to the President through FEMA. A joint FEMA, state and local team will conduct a Preliminary Damage Assessment to determine if there is a need for federal assistance. If federal assistance is justified, the President issues an emergency or major disaster declaration and various emergency or disaster programs are made available. Federal assistance is on a shared cost basis. Major Disaster Declaration (DR-4286) was declared on October 11, 2016 for South Carolina (figure 5).

Once a Presidential declaration has been made, damage that meets all of the following criteria may be eligible for cost-shared FEMA assistance:

- The damage is a direct result of the declared event;

- The damage that occurs can be tied directly to the declared event;

- The damage occurred within the designated disaster area (except sheltering and evacuation activities that may be located outside the designated area);

- The damage is the applicant's legal responsibility at the time of the disaster;

- With very few exceptions, the damage occurred at a facility in active use; and

- The damage is not within the specific authority of another Federal program (Public Assistance Applicant Handbook FEMA P-323 / March 2010).

Public Assistance

- Disaster grant assistance available for communities to quickly respond to and recover from major disasters or emergencies declared by the President

Asistence categories (table 1):

Category A - Debris Removal

Category B - Emergency Protective Measures

Categories C-G - Permanent Work

- Roads and Bridges (Category C)

- Water Control Facilities (Category D)

- Buildings and Equipment (Category E)

- Utilities (Category F)

- Parks, Recreational Areas, and Other Facilities (Category G) 
Figure 5: South Carolina Disaster Declaration

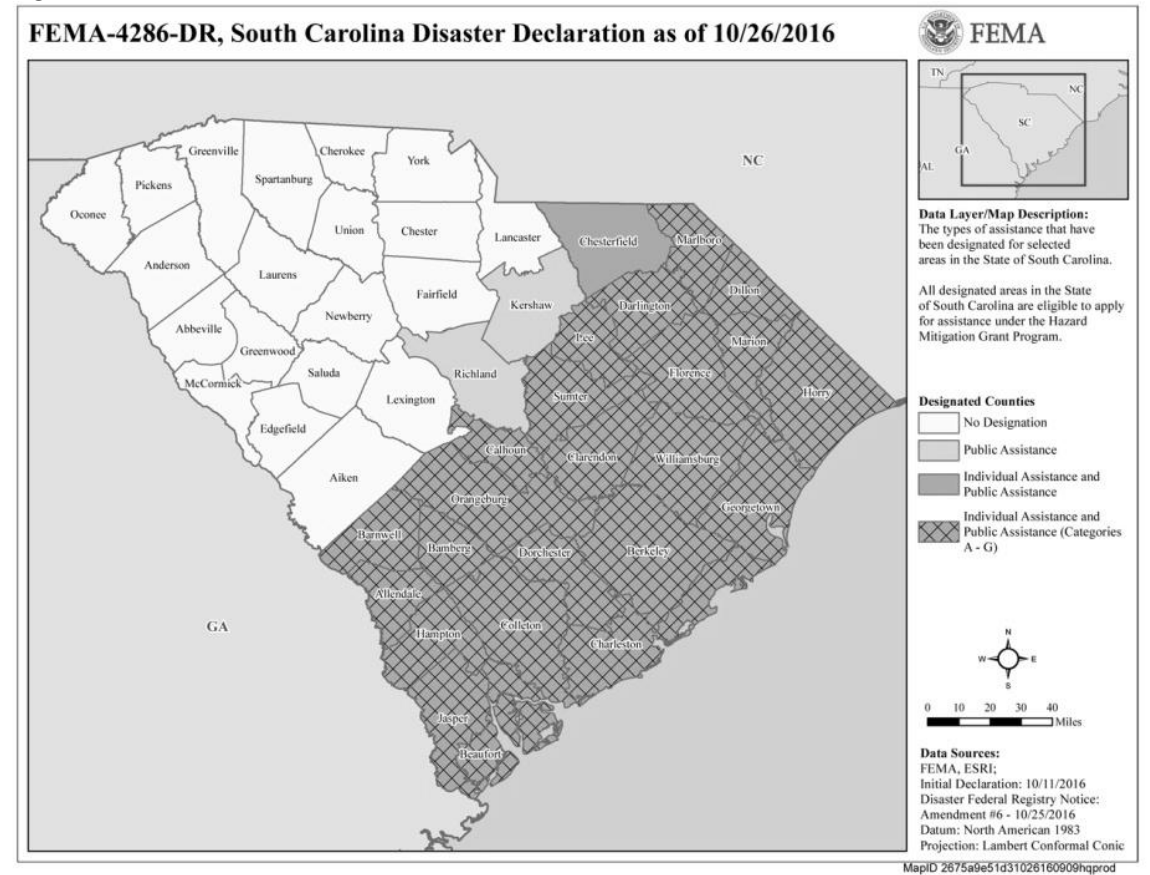

Source: FEMA, 2016

Table 1: Actual claims approved by the federal government (public assistance)

\begin{tabular}{|c|c|c|c|}
\hline $\begin{array}{c}\text { State of South } \\
\text { Caroloina, DR- } \\
\begin{array}{c}4286 \\
\text { Hurricane } \\
\text { Mathew }\end{array}\end{array}$ & $\begin{array}{c}\text { Total Public } \\
\text { Assistance Grants - } \\
\text { Dollars Obligated* }\end{array}$ & $\begin{array}{c}\text { Emergency Work } \\
\text { (Categories A-B) - } \\
\text { Dollars Obligated* }\end{array}$ & $\begin{array}{c}\text { Permanent Work } \\
\text { (Categories C- } \\
\text { G) - Dollars } \\
\text { Obligated* }\end{array}$ \\
\hline Total Amount & $\$ 16,230,314.77$ & $\$ 14,596,254.63$ & $\$ 124,824.14$ \\
\hline
\end{tabular}

*Dollars Obligated: Funds made available to the State via electronic transfer following FEMA's final review and approval of Public Assistance projects. Updated: Sunday, February 26, 2017 (https://www.fema.gov/disaster/4286)

Individual Assistance (table 2):

- Individuals \& Household Program: Provides money and services to people in Presidentially declared disaster areas.

- Housing Assistance: Provides assistance for disaster-related housing needs. 
- Other Needs Assistance: Provides assistance for other disaster-related needs, such as furnishings, transportation, and medical.

Table 2: Actual claims approved by the federal government (individual assistance)

\begin{tabular}{|l|c|c|c|c|}
\hline $\begin{array}{c}\text { State of } \\
\text { South } \\
\text { Caroloina, } \\
\text { DR-4286 } \\
\text { Hurricane } \\
\text { Mathew }\end{array}$ & $\begin{array}{c}\text { Total } \\
\text { Individual } \\
\text { Assistance } \\
\text { (IA) - } \\
\text { Applications } \\
\text { Approved: }\end{array}$ & $\begin{array}{c}\text { Total Housing } \\
\text { Assistance - } \\
\text { Dollars } \\
\text { Approved* }\end{array}$ & $\begin{array}{c}\text { Total Other } \\
\text { Needs } \\
\text { Assistance - } \\
\text { Dollars } \\
\text { Approved* }\end{array}$ & $\begin{array}{c}\text { Total } \\
\text { Individual \& } \\
\text { Households } \\
\text { Program - } \\
\text { Dollars } \\
\text { Approved* }\end{array}$ \\
\hline $\begin{array}{l}\text { Total } \\
\text { Amount }\end{array}$ & 11,535 & $\$ 31,371,538.08$ & $\$ 6,935,645.11$ & $\$ 38,307,183.19$ \\
\hline
\end{tabular}

*Dollars Approved: Assistance dollars approved but not necessarily disbursed. Updated: Sunday, February 26, 2017 (https://www.fema.gov/disaster/4286)

These numbers are only for the actual claims approved by the federal government as of February $26^{\text {th }}$, 2016, many other claims in South Carolina are still pending. For the overall damage it will be long before we get the final numbers but the hurricane probably caused $\$ 10$ billion in damage nationwide including loss of revenue and jobs, according to an estimate from Goldman Sachs. Insurance companies will likely be liable for about $\$ 4$ billion to $\$ 6$ billion of that total, according to an estimate Saturday by CoreLogic, a real estate data provider. But the figures suggest Matthew's effect on the broader national economy will be minimal. Though damage estimates are usually revised higher after more comprehensive assessments, the current figures would still make Matthew the 22nd-worst storm since World War II, Goldman estimates.

By comparison, Hurricane Sandy, the second-worst storm, caused $\$ 15$ billion to $\$ 20$ billion in insured losses and $\$ 50$ billion to $\$ 60$ billion in overall damage in 2012 (http://bigstory.ap.org).

After the initial push and restoring of public services, debris removal becomes the most predominant task to restore the community. Federal Emergency Management Agency's (FEMA) public assistance program typically covers debris removal only on county, city and state roads, posing a problem for Beaufort County where more than $71 \%$ of roads are private and especially a problem for Hilton Head Island. Of the 549 miles of island roads, 437 are private, according to county data (graph 1). 
Graph 1: Breakdown of Hilton Head roads

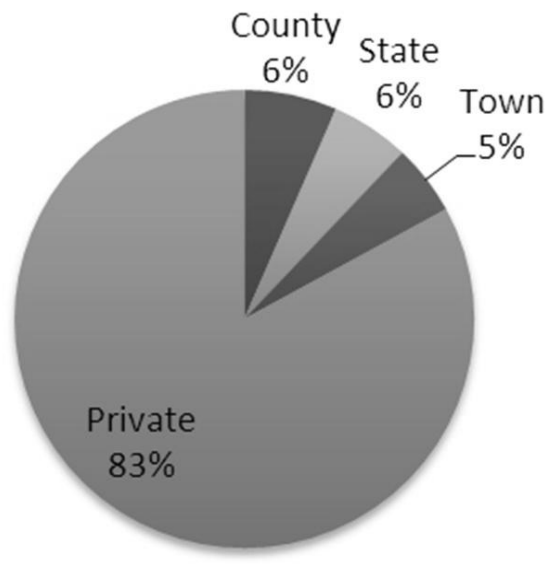

Source: Beaufort County Sheriff's Office, 2016

However, on a case by case basis, FEMA will evaluate requests made to the County by these private communities and allow reimbursement to the County or Town for removing debris in gated communities when the following conditions are met:

- it is required to eliminate or lessen the immediate threat to life, health and safety,

- to reduce a threat of additional damage to improved property, or

- to promote economic recovery of the community at large.

The Town of Hilton Head would not remove debris from private gated communities until FEMA has given the approval to do so otherwise it would not get reimbursed for the portion of costs for cleanup before the final approval. But even if FEMA approve such request the percentage of federal reimbursement rate for debris removal is including the additional 2\% for a FEMA approved disaster recovery plan in place before the disaster:

- For the first 70 hours, FEMA would cover $100 \%$ of the cost of the initial push.

- For the first 30 days, FEMA would cover 87 percent of the cost.

- For the next 60 days, FEMA would cover 82 percent of the cost.

- After 90 days, FEMA would cover 77 percent of the cost.

The remaining costs would be covered by either the county, municipality or individual plantations, depending on how documentation was submitted (Debris piles rise as feds decide if they'll pay for private road cleanup in Island Packet, October $21^{\text {st }}, 2016$ ).

After the initial road push and clearance of debris, as the financial responsibilities were resolved the curbside Pick-Up from Right-of-Way started. 
Residents at this time after the hurricane may bring debris from their properties to public road right-of way for curbside collection. Typical debris placed to the road right of way will consist of:

- Household garbage such as bagged trash, discarded food, packaging, and papers generated during the disaster event

- Construction and demolition materials removed by the homeowner prior to the receipt of insurance and individual assistance payments

- Woody and vegetative debris and yard waste such as tree branches, leaves, and logs

- Household hazardous waste such as oils, batteries, pesticides, paints, cleaning supplies, and compressed gases

- White goods such as refrigerators, washers and dryers, freezers, air conditioners, stoves, water heaters, and dishwashers

- Electronics such as televisions, computers, radios, stereos, DVD players, and telephones.

As well The Town of Hilton Head Island created designated citizen drop off centers for resident citizens to bring disaster related debris to instead of leaving it curb side or for the residents living on streets where their Right of Way is not approved for debris collection. At least one debris monitor must be stationed at each site to assist citizens and monitor eligible debris collections. The debris removal contractor collects the debris from the citizen drop off centers and transports to the Debris Monitoring Site (DMS) locations for segregation and reduction, the final disposal sites, or the hazardous waste management sites.

Each disaster is unique and creates various amounts of different debris and waste. Due to the heavily vegetative characteristics of the Town of Hilton Head Island and since there was only minimal flooding on Hilton Head Island after hurricane Mathew, majority of the debris consisted of whole trees, tree stumps, tree branches, tree trunks, and other leafy material referred to as Vegetative debris. Debris monitors are responsible for determining the eligibility for hazardous trees and stumps during the collection process. This eligibility determination can be challenging using FEMA's criteria:

Hazardous Trees:

A tree is considered hazardous if its hazardous condition was caused by the disaster; it is an immediate threat to lives, public health and safety, or improved property; it has a diameter breast height of six inches or longer; and one or more of the following criteria are met:

- It has more than 50 percent of the crown damaged or destroyed;

- It has a split trunk or broken branches that expose the heartwood;

- It has fallen or been uprooted within a public-use area; and/or

- It is leaning at an angle greater than 30 degrees 
Hazardous trees that have less than 50 percent of the root-ball exposed should be cut flush at the ground level (the resulting stump should not be grinded). Removing the leaning portion of a hazardous tree and cutting the stump at ground level would be considered eligible scope of removal. Hazardous trees may also be straightened and braced if it is less costly then removing and disposing of the tree.

\section{Hazardous Limb Removal (Hangers)}

Eligible limbs for removal must have the following criteria:

- Located on improved public property

- Greater than two inches in diameter at the point of breakage

- Still hanging in a tree and threatening a public-use area

\section{Hazardous Tree Stumps}

A tree stump may be determined hazardous and eligible debris if it meets the following criteria:

- It has 50 percent or more of the root-ball exposed (less than 50 percent of the root-ball exposed should be flush cut)

- It is greater than 24 inches in diameter, when measured 24 inches above ground

- It is on improved public property or public right-of-way

- It poses an immediate threat to life, and public health and safety (figure $6,7)$

Figure 6: Hazardous trees in HHI

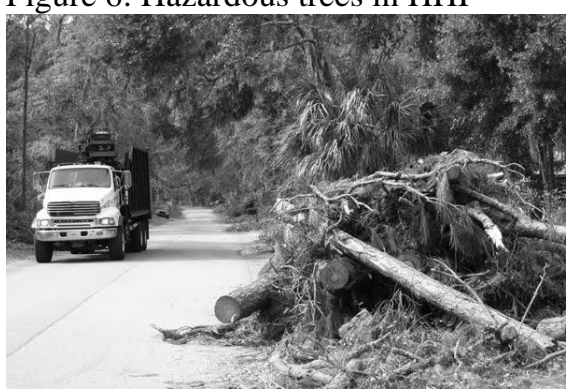

Source: Kráner, 2016
Figure 7: Hazardous trees in $\mathrm{HHI}$

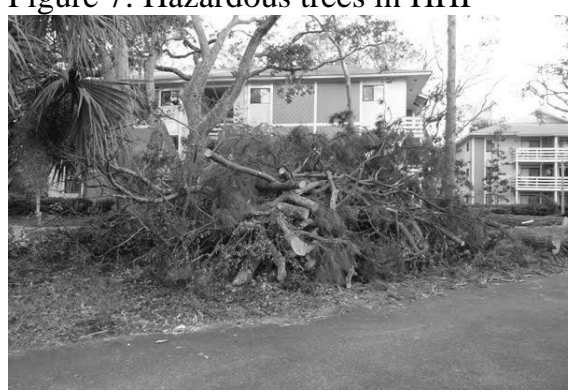

Source: Kráner, 2016

Total Vegetative Debris Collected on Hilton Head Island as of 3/9/2017 was 2,135,387 cubic yards (graph 2,3) Hangers (hanging limbs) Removed: 42,10 Leaners (leaningtrees) Removed: 5,31 Mulch Hauled Out to final deposition sites 832,226 cubic yards (https://www.hiltonheadislandsc.gov/recovery/debris info.cfm) 
Graph 2: Actual vs. Estimated Debris Comparison in Cubic Yards

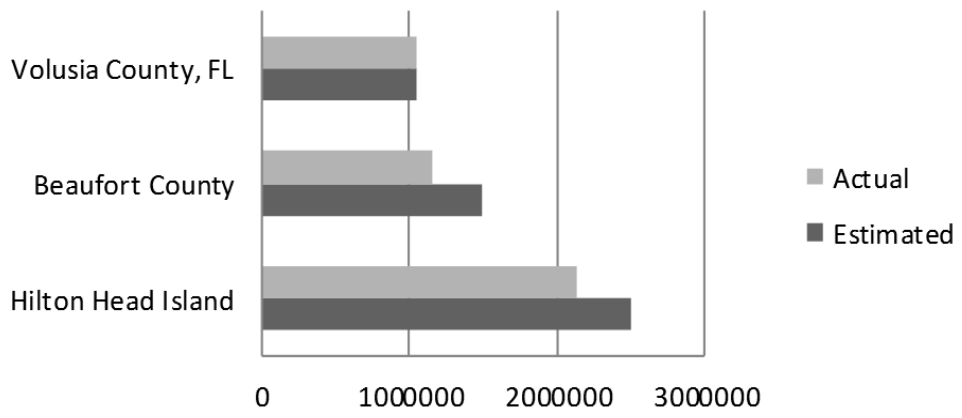

Source: www.hiltonheadislandsc.gov

Graph 3: Estimated Cubic Yards of Debris Per Acre

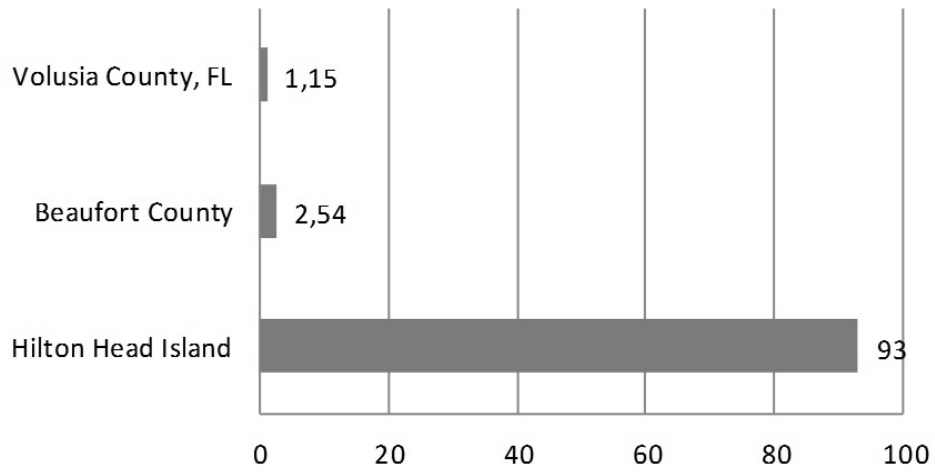

Source: www.hiltonheadislandsc.gov

Hurricane Mathew caused considerable damage to the buildings on the island. The Assessments for each of the 19,688 structures on the Island has been completed after the hurricane. Each building was inspected and a color coded place card was placed on the building.

A green placard indicates that any damage sustained by a building is minor or superficial, and that the building is safe to enter and use. Actions such as replacing broken glass, repairing roof tiles, and replacing garage doors will require no further permits from the Town (figure 8,9).

A yellow placard indicates that a building has sustained more than minor damage, and only partial entry or occupancy is allowed until repairs are made. The owner should contact the Emergency Permitting Office to obtain a building permit before going forward with repairs. 
A red placard indicates that a building is seriously damaged, and is unsafe. These buildings should not be entered or occupied under any circumstance. Entry could result in injury or death. The building may be repaired or demolished, but in either case, a permit must be obtained from the Emergency Permitting Office before work begins.

Figure 8: Examples of inspection cards

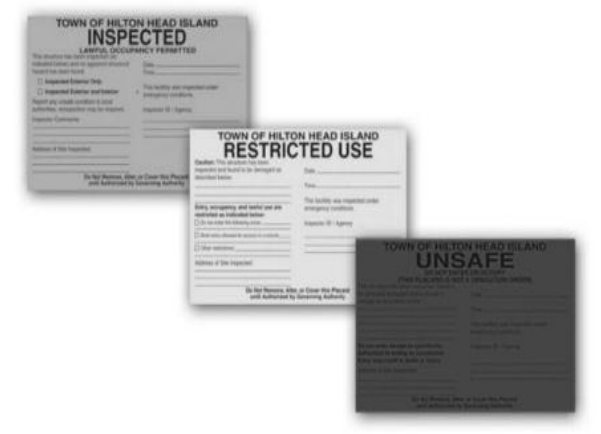

Source: Kráner, 2016
Figure 9: Actual Inspection card on residential building 11 Gold Oak CT, Hilton Head island

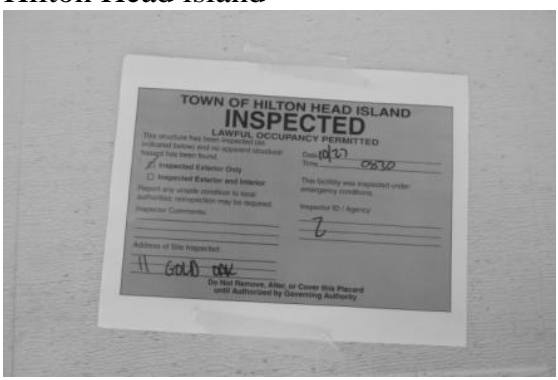

Source: Kráner, 2016

\section{Conslusion}

Damaged structures account for less than $15 \%$ of all structures and those with at least $50 \%$ damage account for less than $1.5 \%$ of all structures.

In the aftermath of the Oct. 8 hurricane the storm severely depleted reserve funds in some private communities, and the responsibility to replenish those reserves likely will fall primarily on residents if little insurance or governmental aid is available.

U.S. Small Business Administration (SBA) is the federal government's primary source of money for the long-term rebuilding of disaster- damaged private property. SBA helps businesses of all sizes, private non-profit organizations, homeowners and renters fund repairs or rebuilding efforts and cover the cost of replacing lost or disaster-damaged personal property. These disaster loans cover losses not fully compensated by insurance or other recoveries and do not duplicate benefits of other agencies or organizations. Low-interest disaster loans are available to homeowners and renters, as well as businesses of all sizes, including landlords and private nonprofit organizations. Home private homeowners associations on Hilton Head are raising residents' fees to recover costs from Hurricane Matthew, while other off-island, gated communities aren't planning to do so - at least for now.

Following a natural disaster, local residents might see an increase in property taxes. In private communities when there's a major expense that's not 
covered by insurance, every single owner is responsible for the debts and liabilities of the private association.

Efforts by several Hilton Head Island communities to recoup hurricane-related costs are done by rising assessments. Here is an example of how some of the communities intend to replenish their emergency funds and pay for the storm related expenses.

- Annual assessment fees at Hilton Head Plantation will rise by $\$ 250$ more than initially planned

- Palmetto Dunes residents will face a $\$ 150$ storm fee next year and likely for two more years

- Sea Pines is imposing a one-time special assessment of $\$ 1,018$ for improved lots and $\$ 607$ for unimproved lots to recover an estimated $\$ 5.2$ million in hurricane-related damage, officials there said.

- The approximately 300 residents of the island's Broad Creek Landing community face an even steeper price tag.

- Broad Creek Landing's private owners association (POA) is assessing an additional approximately $\$ 2,500$, depending on the size of the unit. The special fee will be paid in two payments, to recover the estimated $\$ 737,000$ in storm costs.

Some Beaufort County communities are

- Windmill Harbour, Port Royal Plantation, Indigo Run and Long Cove Club are waiting on others who might foot a portion of their bills before deciding if additional assessments are necessary (http://www.islandpacket.com).

\section{References}

BEAUFORT COUNTY 2011-2012 Disaster Recovery Plan, 2011, 313p.

BEAUFORT COUNTY Hazard Mitigation Plan 2015 Update, 2015, 228 p.

FEDERAL EMERGENCY MANAGEMENT AGENCY, Public Assistance Applicant Handbook FEMA P-323, March 2010, 134 p.

HEFTER, N. 1998. Images of America, Hilton Head Island. Charleston: Coastal

Discovery Museum, 1998. 145 p. ISBN 98-88303.

PUBLIC ASSISTANCE DEBRIS MANAGEMENT GUIDE FEMA-325, July 2007, $260 \mathrm{p}$.

SOUTH CAROLINA HURRICANE GUIDE, 2016, 14 p.

TOWN OF HILTON HEAD ISLAND, South Carolina, Consolidated Municipal

Budget Fiscal Year July 1, 2007 through June 30, 2008, 2008, 141 p.

TOWN OF HILTON HEAD ISLAND, South Carolina, Consolidated Municipal

Budget Fiscal Year July 1, 2014 through June 30, 2015, 2015, 153 p.

TOWN OF HILTON HEAD ISLAND, South Carolina, Consolidated Municipal

Budget Fiscal Year July 1, 2016 through June 30, 2017, 2016, 194 p. 


\section{Internet sources:}

http://www.dnr.sc.gov/climate/sco/Tropics/hurricanes_affecting_sc.php

http://www.fema.gov/disaster/4286

http://www.irinfo.org/08-01-2005-brady/

http://www.seapines50thanniversary.com/

http://www.dnr.sc.gov

https://www.hiltonheadislandsc.gov/publications/guides/CititzenGuideToEmergen cyPrep.pdf

http://www.sailingscuttlebutt.com/2016/10/09/recap-hurricane-matthews-

destruction/

http://www.usatoday.com/story/weather/2016/10/08/hurricane-matthew-economicdamage-cost-6-billion/91783304/

http://hurricane-facts.com/

http://www.spinnakerresorts.com/blogs/hilton-head-island-blog/item/spinnakerresorts-vs-hurricane-matthew

http://www.hiltoheadislandsc.gov/publicsafety/huricane

http://bigstory.ap.org/article/63831a5057bd40f496921b3bcb6b0084/closed-us-

restaurants-damaged-homes-matthew-may-cost-10b

https://www.hiltonheadislandsc.gov/recovery/debrisinfo.cfm

http://www.islandpacket.com/news/weather/hurricane/article118669853.html)

\section{Mgr. Adrián Kráner}

E-mail: adriankraner@yahoo.com

\section{RNDr. Lucia Šolcová, PhD.}

Katedra geografie a regionálneho rozvoja FPV UKF v Nitre

Trieda A. Hlinku 1, 94974 Nitra

E-mail: lsolcova@ukf.sk 